\title{
Reconstruction of Historic Forest Cover Changes Indicates Minor Effects on Carbon Stocks in Swiss Forest Soils
}

\author{
Sia Gosheva, ${ }^{1,2 *}$ Lorenz Walthert, ${ }^{1}$ Pascal A. Niklaus, ${ }^{2}$ \\ Stephan Zimmermann, ${ }^{1}$ Urs Gimmi, ${ }^{1}$ and Frank Hagedorn ${ }^{1}$
}

${ }^{1}$ Swiss Federal Institute for Forest, Snow and Landscape Research (WSL), Zürcherstr. 111, 8903 Birmensdorf, Switzerland; ${ }^{2}$ Institute
of Evolutionary Biology and Environmental Studies, University of Zurich, Winterthurerstrasse 190, 8057 Zurich, Switzerland

\section{Abstract}

Forest cover in Switzerland and other European countries has gradually increased in the past century. Our knowledge of the impacts of forest expansion and development on soil organic carbon (SOC) storage is, however, limited due to uncertainties in land-use history and lack of historical soil samples. We investigated the effect of forest age on current SOC storage in Switzerland. For 857 sites, we analysed SOC stocks and determined the minimal forest age for all presently forested sites using digitized historical maps, classifying all sites into three categories: young ( $\leq 60$ years), medium (60-120 years), and old ( $\geq 120$ years) forests. Grassland was the primary previous use of afforested land. Forest age affected current SOC stocks only moderately, whereas climate, soil chemistry, and tree species exerted a stronger impact. In the organic layer, highest SOC stocks were found in medium sites

Received 22 November 2016; accepted 16 February 2017;

published online 27 March 2017

Electronic supplementary material: The online version of this article (doi:10.1007/s10021-017-0129-9) contains supplementary material, which is available to authorized users.

Author contributions SG performed the research, analysed the data, and co-wrote the paper; LW and SZ provided the data; PAN and UG contributed new methods to the data analysis; FH designed the study, analysed the data, and co-wrote the paper.

*Corresponding author; e-mail: sia.gosheva@wsl.ch $\left(3.0 \pm 0.3 \mathrm{~kg} \mathrm{C} \mathrm{m}^{-2}\right)$. As compared to other age categories, these sites had a $10 \%$ higher cover in coniferous forests with higher organic layer $\mathrm{C}$ stocks than broadleaf forests. SOC stocks in mineral soils decreased with increasing forest age (12.5 \pm 0.9 , $\left.11.4 \pm 0.5, \quad 10.5 \pm 0.3 \mathrm{~kg} \mathrm{C} \mathrm{m}^{-2}\right)$. This decrease was primarily related to a $200-\mathrm{m}$ higher average elevation of young sites and higher SOC stocks in a colder and more humid climate. In summary, forest age has only a minor effect on SOC storage in Swiss forest soils. Therefore, ongoing forest expansion in mountainous regions of Europe is unlikely contributing to soil $\mathrm{C}$ sequestration.

Key words: carbon sequestration; land use; landuse history; forest age; minimal forest age; forest expansion; soil organic matter; soil organic carbon; swiss forest soils.

\section{INTRODUCTION}

Soils represent the largest carbon (C) reservoir in terrestrial ecosystems (Schmidt and others 2011; Scharlemann and others 2014)-globally, the quantity of soil organic carbon (SOC) is about three times larger than the amount stored in vegetation and twice as much as in the atmosphere (Ciais and others 2013). Forest soils are particularly carbon- 
rich (Lorenz and Lal 2010) and therefore imperative when considering carbon storage for greenhouse gas (GHG) inventories. Land-use change (LUC) alters C storage in biomass as well as in soils (Guo and Gifford 2002; Lal 2005; Poeplau and others 2011; Fuchs and others 2016). Changes in land use affect both the formation and the decomposition of SOC, which could turn soils into either a sink or a source of atmospheric $\mathrm{CO}_{2}$ concentrations (Poeplau and others 2011; Hiltbrunner and others 2013; Bárcena and others 2014). The effects on the net $\mathrm{C}$ balance of soils, however, are often uncertain as our current knowledge is primarily based on case studies, and effect sizes and even directions depend on the type of LUC as well as on time (Poeplau and others 2011; Hiltbrunner and others 2013).

Since the 1950s, European forest areas have expanded by over 25\% (Janssens and others 2003; Kümmerle and others 2015), whereas cropland and grassland areas have steadily declined (Rounsevell and others 2003, 2006). In Central and South European mountainous areas, between 1990 and 2000 over $4 \%$ of agricultural land has been abandoned (Sjögersten and others 2011). In Switzerland, forest expansion has been the major land-use change with an areal increase of approximately $22 \%$ in the last century (Ginzler and others 2011). Currently, forests account for one-third of the country's area (Bolliger and others 2008; Brändli 2010). Similar to other CentralEuropean countries, the largest forest expansion has occurred on marginal land in alpine regions, primarily at the expense of grassland (Gellrich and others 2007; Brändli 2010). In comparison with many other European regions, forests in Switzerland have primarily been managed as plenter forests with single-tree harvest and consequently a near-natural structure of forests (Angst 2012). Due to high costs of wood harvesting, the management intensity has even declined during the last decades (Brändli 2010). As a consequence, Swiss forests are characterized by a high mean tree age (more than $1 / 4$ of Swiss accessible forest area is older than 120 years, see Brändli and others 2015) and by the greatest stand biomass in Europe (Liski and others 2002).

Forest expansion and development ultimately alters the climatic balance of terrestrial ecosystems including both radiative forcing via albedo changes and $C$ sequestration. In these estimates, changes in SOC stocks represent the largest uncertainty (for Switzerland, see Schwaab and others 2015; for Europe: Fuchs and others 2016). Generally, forest soils contain high SOC stocks (Lal 2005) and thus, newly afforested soils are assumed to become a $\mathrm{C}$ sink due to reduced biomass removal, a larger rooting system with greater $C$ input into the soil, and low litter quality (Lorenz and Lal 2010; Fuchs and others 2016). Deforestation and forest disturbance have frequently been observed to induce rapid SOC losses (Spielvogel and others 2006; Poeplau and others 2011; Achat and others 2015; Guillaume and others 2015), which in reverse suggests that forest expansion would lead to net soil $\mathrm{C}$ gains, but probably at a smaller rate (Jandl and others 2007). However, a number of recent case studies challenge this paradigm. Whereas an increase in SOC stocks is observed during cropland afforestation, the direction and magnitude of SOC storage is not as straightforward in the case of grassland afforestation. Hiltbrunner and others (2013), for example, found that afforestation of extensively grazed subalpine pasture had only a small effect on total SOC storage, with increasing stocks in the organic layer but decreasing SOC stocks in the mineral soil. Correspondingly, afforestation of abandoned subalpine grasslands in the Italian Alps decreased SOC stocks down to a soil depth of $30 \mathrm{~cm}$ (Guidi and others 2014), but in the German Alps the decline in the mineral soil was offset by a SOC accumulation in the organic layer (Thuille and Schulze 2006). Most studies only include surface soils when examining afforestation effects but $\mathrm{C}$ gains in surface soils are often offset by C losses in the subsoil (Vesterdal and others 2002, 2011; Poeplau and others 2011; Hiltbrunner and others 2013; Mobley and others 2015). Moreover, the type of the previous land use plays a crucial role for the afforestation effects with larger increases on former crop than on grassland (Poeplau and others 2011). In addition, SOC stock changes also depend on time since LUC has occurred, including a transition period following forest expansion, during which SOC stocks initially decrease and thereafter recover (Bárcena and others 2014). For example, case studies in the Netherlands indicate that organic layer only starts to accumulate 8 years after tree stands have been established (Vesterdal and others 2002) and converge to a higher 'steadystate' level after about 80-100 years (Böttcher and Springob 2001). Reflecting the observed patterns, soil C models suggest a sigmoidal increase of SOC stocks during forest development with a negligible initial increase of SOC stocks followed by high accumulation rates that eventually level out (Jandl and others 2007; Thürig and Kaufmann 2010). Thus, forest age is assumed to be crucial in predicting the time scales of the processes influencing SOC dynamics in forest soils. The magnitude and 
temporal dynamics, however, remain highly uncertain.

Historical land use has been recognized as relevant for current soil properties (Dupouey and others 2002; Gimmi and others 2013). Even though historical land-use practices have been shown to influence SOC stocks in the long-term (Schulp and Verburg 2009; Bárcena and others 2014), our quantitative knowledge is still limited due to the lack of historical soil samples and an uncertain land-use history. Most knowledge about afforestation effects on SOC stocks originates from a limited number of chronosequence studies (Bellemare and others 2002; Vesterdal and others 2002; Hiltbrunner and others 2013). An alternative approach is to assess the historical land use for a large number of sites and to estimate how current SOC stocks differ among soils with different land-use histories. For instance, Schulp and Verburg (2009) showed that historic land use (for example, forest degrading to heath) in the Netherlands is still imprinted in current SOC stocks. In contrast, historic forest management (for example, former selectively cut forests) was not reflected in current SOC stocks in the Hainich-Dün region in Germany (Wäldchen and others 2013).

In our study, we assessed the impact of ongoing forest expansion on SOC storage in Switzerland. Using historical and modern topographic maps, we reconstructed forest cover changes for the past 150 years and estimated the age of 857 current forest stands for which data on soil, vegetation and environment had been measured. Then, we examined the effect of forest age on current SOC stocks in the organic layer and mineral soil and compared it to other factors such as topography, climate, and soil properties. We expected that SOC stocks would increase with increasing forest age reflecting forest development but that the effect of forest age would be small as compared to the influence of forest type, climatic parameters and physico-chemical soil characteristics.

\section{Materials AND Methods}

\section{Study Area and Sampling Sites}

A total of 1047 soil profiles have been sampled across the entire forested territory of Switzerland (Figure 1). Switzerland can be categorized into five major biogeographic regions (Jura, Plateau, PreAlps, Alps, and Southern Alps) with specific climatic conditions, bedrock, and forest cover. The Jura, the Plateau, the Pre-Alps, and the northern part of the Alps are characterized by an oceanic and thus relatively humid climate, whereas the central part of the Alps has a continental climate. The Southern Alps have warm temperate so-called insubrian climate conditions (Gonseth and others 2001). The Jura is dominated by calcareous bedrock like limestone or marl, whereas the Southern Alps have mainly acidic bedrock such as granite or gneiss. The other regions have various types of bedrocks with the Plateau comprising mainly calcareous moraines or tertiary sediments (molasse), the Pre-Alps consisting mostly of calcareous sediments, and the Alps having very heterogeneous bedrocks (Gnägi and Labhart 2015). Forest covers almost half of the Jura (48\%) and of the Southern Alps (47\%), 25\% of the Plateau, 33\% of the PreAlps, and $22 \%$ of the area of the Alps region (Swiss National Forest Inventory, Brändli 2010). The fraction of conifer forest is greatest in the Alps $(76 \%)$ and smallest in the Southern Alps $(38 \%$; Brändli 2010). The majority of our sampling sites are located on the Plateau $(n=277)$ and in the PreAlps $(n=260)$. The rest of the sites are distributed across the Alps $(n=176)$, Jura $(n=73)$, and the Southern Alps $(n=71)$. All sites are located in current forests with elevations ranging between 277 and $2207 \mathrm{~m}$ a.s.l..

\section{Soil Data}

The morphology of all soil profiles was determined and samples were collected by genetic horizons, down to $120 \mathrm{~cm}$ soil depth on average or to parent rock. Samples were dried at $40-60^{\circ} \mathrm{C}$ and sieved with a $2-\mathrm{mm}$ mesh for chemical analysis. Soil $\mathrm{pH}$ was measured in $0.01 \mathrm{M} \mathrm{CaCl}_{2}$. Basic cation contents (BC), comprising the sum of the exchangeable basic cations ( $\mathrm{Ca}, \mathrm{Mg}, \mathrm{K}$, and $\mathrm{Na}$ ), was determined by extraction with unbuffered $1 \mathrm{M}$ $\mathrm{NH}_{4} \mathrm{Cl}$ (soil/solution = 1:10, end-over-end shaker for 1 hour) and measured by an ICP-OES (Perkin Elmer Optima 7300DV) according to Walthert and others (2013). Humus forms were classified into: mull (only litter horizon present), moder $(L+F$ horizon present), and mor ( $L, F$, and $H$ horizons present). Total and organic $C$ contents were measured in ground samples by dry combustion using a C/N analyser NC 2500 (CE Instruments, Italy). Inorganic $\mathrm{C}$ in samples with a $\mathrm{pH}$ above 6.0 was removed with acid vapour prior to analysis (Walthert and others 2010). Mineral soil SOC stocks were calculated using the following equation:

$$
\operatorname{SOC}_{h z}=\sum_{i}^{z}\left(h_{i}\left(1-\theta_{i}\right) \rho_{i} C_{i}\right)
$$




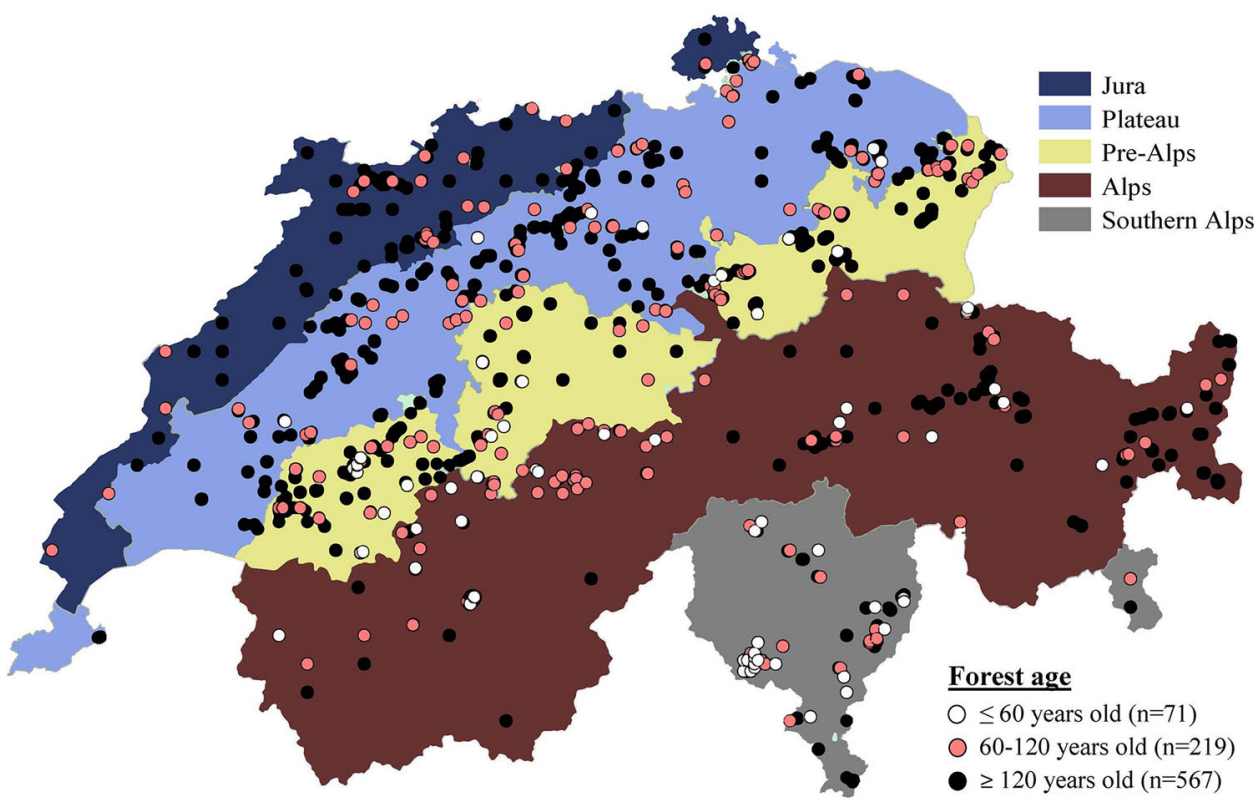

Figure 1. Map of Switzerland showing the distribution of the forest soil sites $(n=857)$ according to forest age classes. where $\mathrm{SOC}_{h z}$ is the SOC stocks of all horizons

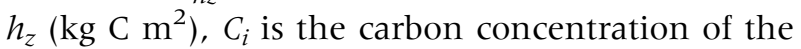
horizon $i\left(\mathrm{~kg} \mathrm{~kg}^{-1}\right), \rho_{i}$ is the density of the fine earth $\left(\mathrm{g} \mathrm{cm}^{-3}\right), \theta_{i}$ is the volumetric stone content $\left(\mathrm{m}^{3} \mathrm{~m}^{-3}\right)$, and $h_{i}$ is the horizon thickness $(\mathrm{m})$. Fine earth density was estimated with a pedotransfer function, based on a calibration dataset of 559 mineral soil horizons from 134 different sites and a validation set of 131 horizons from 34 sites (see Nussbaum and others 2016 for details). The pedotransfer function relied on the SOC content, the square root of the sampling depth, the square root of the slope, the skeleton content, three field density estimates, and nine physiographical unit categories. The SOC stock in the organic layer was calculated according to Hagedorn and others (2010), where the mass of the organic layer was first calculated as a product of the density ( $F$ $0.15 \mathrm{~g} \mathrm{~cm}^{-3}, H 0.20 \mathrm{~g} \mathrm{~cm}^{-3}$ ) and the volume (based on measured thicknesses), which was then multiplied with its C concentration. Finally, as soil profiles have been dug vertically, SOC stocks were corrected for the slope by multiplying them with the cosine of the slope. Carbon stocks were calculated for the organic layer (including $L, F$, and $H$ horizons), for the mineral soil at 0-120 cm depth and for total carbon stocks equalling the sum of the two. Mean average contents of $\mathrm{BC}$ and $\mathrm{pH}$ were calculated for 0 to 30 and 0 to $120 \mathrm{~cm}$ depth intervals by weighting the averages of the contents with the amount of fine earth. Clay, silt, and sand contents of 600 sites were measured with the sedimentation method according to Gee and Bauder
(1986). Field estimates, according to ten soil texture classes, were used for the rest of the samples (Walthert and others 2013). Soil type was classified according to the World Reference Base from 2007 (IUSS Working Group WRB 2007), and soil types were grouped into calcareous, acidic, and waterlogged soil groups. Calcareous and acidic soils were separated by setting the lime limit to one metre soil depth, while the waterlogged soils comprised Gleysols and Stagnosols. Rooting depth was assessed directly in the soil pits.

\section{Relief, Climatic, and Vegetation Data}

Altitude and slope were determined from a 25-m digital elevation model (DEM, Swisstopo 2011). Climate data were based on the Swiss meteorological network MeteoSwiss combined with suitable interpolation methods. Mean annual precipitation (MAP) and temperature (MAT) for the period 19812010 were provided by Meteotest (see Remund and others 2014 for details). Plant species in herb, shrub, and tree layers were determined using the BraunBlanquet cover abundance scale (Braun-Blanquet 1964). The broadleaf percentage was calculated as the sum of the cover of all broadleaf species divided by the sum of the cover of all tree species at canopy level. Using this percentage, forest type was subdivided into two classes: coniferous (0-50\%) and broadleaf $(51-100 \%)$ forests. Exposition and relief were measured directly at the soil pit according to their position in the field (for example, north-west for exposition and hilltop for relief). 


\section{Reconstruction of Past Forest Cover Change}

Historic forest cover change at the 1042 sampling sites was determined by analysing historical and modern topographic maps across Switzerland at eight time periods. The oldest map showing forest cover for Switzerland is the so-called Dufour original survey map which dates back to 1850 (Figure 2A, D). This map has a scale of 1:25000 in the Swiss Plateau and Jura and 1:50000 in Alpine regions. For the 1900-1950 period, Siegfried maps, with the same scale as the Dufour maps, were used (Figure 2B, E). For 1950-2011, modern topographic maps were available (Figure 2C, F, Swisstopo 2011). All maps were available in digitized and geo-referenced form; spatial accuracy of the digitized maps was evaluated by comparing intersection of coordinate lines with modern topographic maps (Ginzler and others 2011). Because each map set was generated over a period of 10-20 years, we examined forest cover changes not for single years but for time periods (1850, 1880-1900, 1910-1920, 1920-1930, 1952-1970, 1970-1990, 1990-2011, 2011).

Forest cover was classified into four categories: forest, open forest, forest edge, and non-forest. The distinction between closed forest, forest edge, and an open forest was done based on the distance of a site to the mapped forest edge. A site was classified as a closed forest site if it was located at least $25 \mathrm{~m}$ from the mapped forest edge (inside buffer). A nonforest site was defined as a site at least $50 \mathrm{~m}$ from the mapped forest edge (outside buffer). A site was classified as forest edge when it was $\pm 25 \mathrm{~m}$ from the mapped forest edge (inside and outside buffer). Finally, a site was classified as open forest when the map showed a tree canopy that did not form a continuous closed cover. Some maps covering the 1850-1900 periods had missing map parts. As a result, it was impossible to identify forest cover for 89 sites, which were removed from further analysis. Five sites, classified as Histosols, were excluded from the analysis due to their extraordinary properties.

Only the sites classified as forest sites in 2011 were considered in the estimation of the forest age. Furthermore, sites were only included in the analysis if there were no interruptions in the forest cover for more than 20 years. Overall, our analysis allowed the estimation of the minimal forest age for 857 currently closed forested sites. The forest sites were subdivided into three time periods of minimal forest ages-sites of at least 120 years of age (here referred to as 'old forest sites') as well as two younger forest site groups, including sites of forest age between 60 and 120 years (here referred to as 'medium') and sites younger than 60 years (here referred to as the 'young'). All map evaluations were completed with ArcGIS 10.1 software.

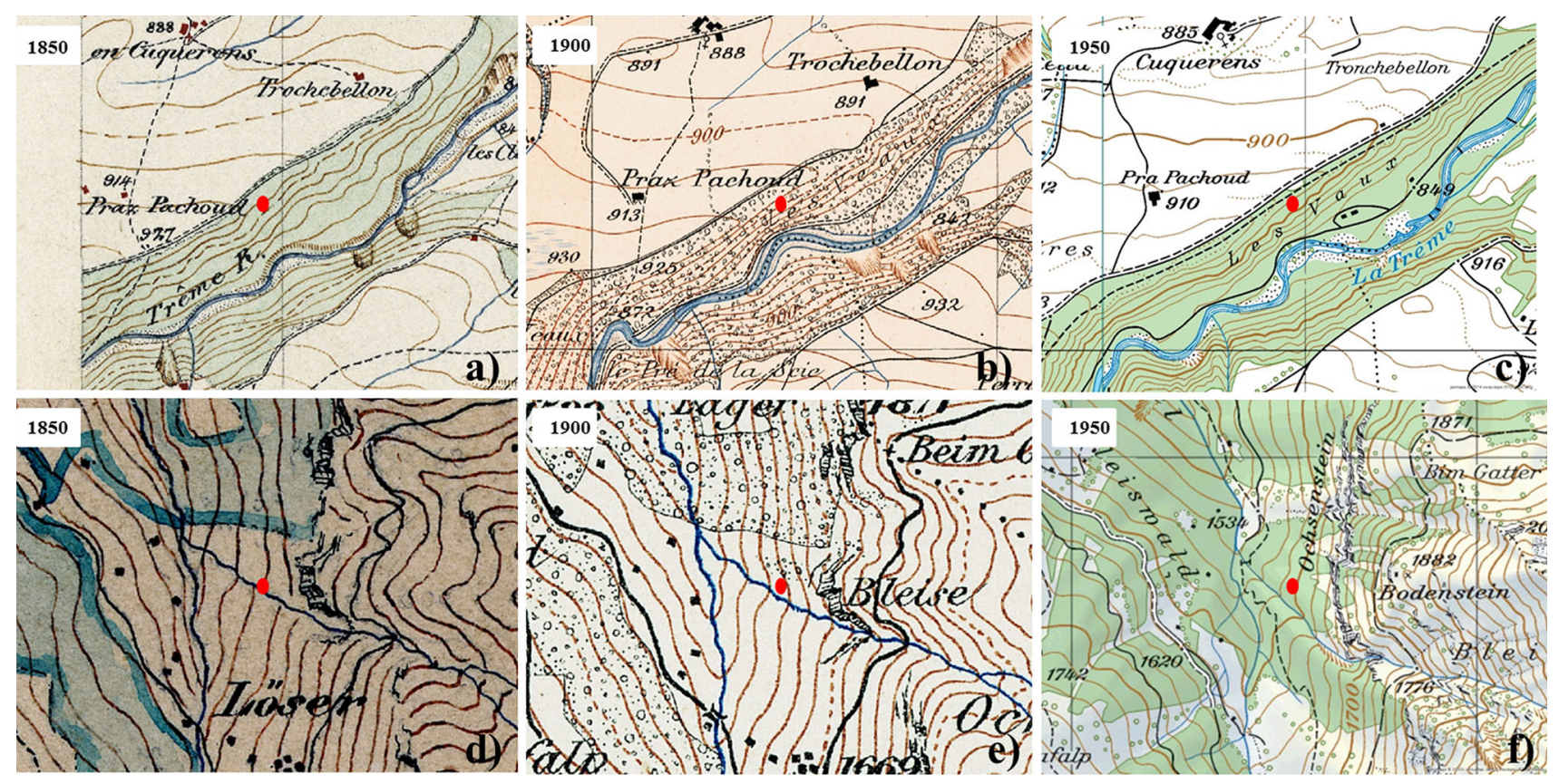

Figure 2. Examples of historical land-use change of soil sites in old forest with a permanent forest cover $(\mathbf{A}, \mathbf{B}, \mathbf{C})$ and in a newly afforested $(\mathbf{D}, \mathbf{E}, \mathbf{F})$ forests. 


\section{Statistical Analysis}

Analysis of variance (ANOVA) tests after variable selection were used to detect if forest age affects SOC stocks as well as to identify the variables with the strongest effect on SOC stocks. All statistical tests were performed in the statistical software R 3.0.3 ( R Core Team 2015; Harrell and Others 2015; Heiberger 2015; Neuwirth 2014, Ripley 2015; Venables and Ripley 2002; Lemon 2006; Wickham 2007, 2009, 2011, 2015; Wickham and Francois 2015). For the variable selection, SOC stocks and the other variables were fed into a regression tree model (Rpackage 'tree') to define which were important determiners of SOC stocks (Crawley 2007). The following variables were fed into tree models: altitude, forest type, root depth, soil group, topography (exposition, relief, slope), climate (MAP and MAT), soil texture (clay, silt, sand contents), soil chemistry (pH and $\mathrm{BC}$ contents). The variables, selected by the tree model as most appropriate, were then included in an ANOVA model. In addition to the tree regression model selection, we identified inter-correlated variables and excluded the ones with the weaker explanatory power to prevent further correlations. The following variables were excluded from further analysis: for organic layer, mineral soil, and total SOC stocks-root depth, slope, clay, and silt contents; for organic layer-MAP, slope, sand contents, altitude, relief; for mineral soil-MAT and relief; for total SOC stocks-altitude, MAT, and sand content. To determine the order in which the variables were fed into the ANOVA model, simple regressions were used to detect whether the variables correlate with forest age. The ones correlating with age were fed after forest age in the model and the ones not correlated-before forest age. In the ANOVA, we used the function Aov.ko with a keep.order option set true to prevent reordering of independent variables in the model. The ANOVA models were checked for multicollinearity using the variance inflation function (VIF, R-package ' $\mathrm{HH}^{\prime}$ ), setting the value of 5 as a threshold for evidence of multicollinearity. Tests were performed for SOC stocks in the organic layer and the mineral soil, as well as for total SOC stocks. Models were manually fitted to the minimum adequate model until all terms in the model were significant. As a post-hoc test, the Tukey's HSD test was performed to determine which of the forest age classes differ significantly from each other. In order to avoid confounding effects by waterlogged soils with very high SOC stocks, we analysed the dataset twice, once including and once excluding them $(n=125)$. In addition to forest age, sites were examined according to forest type, regardless if this occurred in the tree model or not (which it did in the organic layer and total SOC stocks but not in the mineral soil). Furthermore, interactions were included in the tests (forest age $\times$ soil group, region $\times$ soil group, soil group $\times B C, p H \times$ forest type). Due to the non-normality of our dataset, SOC stocks were logtransformed to approximate normality. The normality of the residuals was tested using histograms and Shapiro-Wilk Normality test. The data in the manuscript is presented as means \pm standard error. Effects with $P<0.05$ are considered statistically significant, while $P$ values $<0.1$ are considered marginally significant.

\section{Results}

\section{Site and Soil Characteristics}

The soil sampling sites in current Swiss forests have a MAT ranging from 0.6 to $11.9^{\circ} \mathrm{C}$ and a MAP from 705 to $2340 \mathrm{~mm}$. Predominant soil types were Cambisols $(n=320)$, Luvisols $(n=115)$, and Gleysols $(n=80)$; soils groups were almost equally distributed between calcareous $(n=390)$ and acidic $(n=324)$ sites, whereas waterlogged $(n=125)$ were the smallest group. There were 415 sites covered by broadleaf trees, 422 coniferous sites, and 20 sites, where information on tree species was not available. The $\mathrm{pH}$ values of soil depth $0-30 \mathrm{~cm}$ ranged between 2.8 and 7.8 , and at a depth of $0-120 \mathrm{~cm}$, it ranged between 2.8 and 7.9.

\section{Reconstruction of Forest Cover}

The reconstruction of the past forest cover of currently forested sites using historical maps showed distinct changes in the distribution of closed and open forests, forest edges, and non-forested land (Figure 3). In the first mapping year in 1850, 157 of the 958 sampled sites have been non-forested, whereas this number has drastically decreased 100 years later, with most of these sites transitioning to closed forest. Changes in sites at the forest edge decreased from 120 in 1850 to 90 in 2011 , whereas open forest sites were always less than 20 .

For the estimation of the minimal forest age, only sites located in currently closed forest areas were considered ( $n=857$; Figure 3$)$. This rather strict site selection helped to prevent inclusion of ambiguous sites, such as sites with a short discontinuity in forest cover. The analysis of minimal forest ages indicated that 71 sites belonged to the group of forest sites younger than 60 years, 219 to the sites between 60 and 120 years, and finally 567 were identified as old forest sites with a forest age of at least 120 years. 


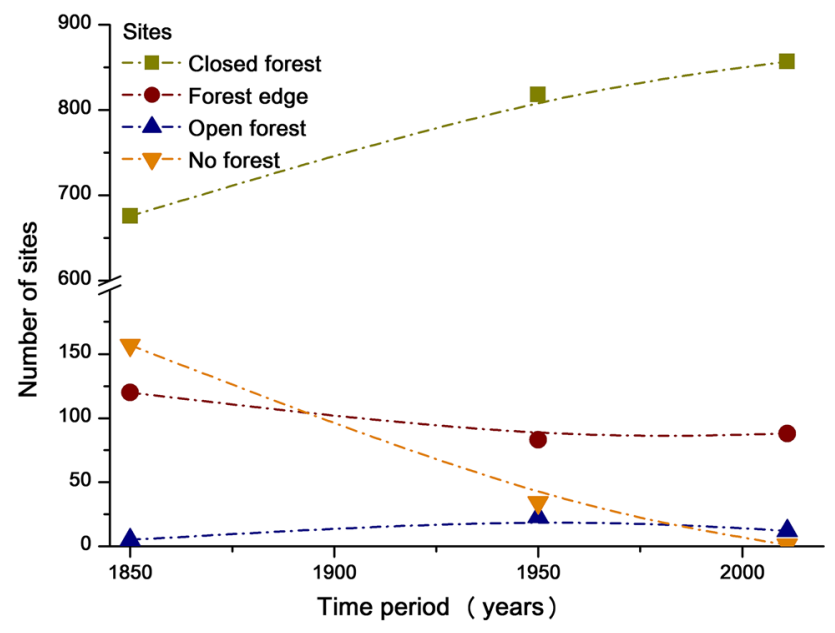

Among the five biogeographic regions, the highest fractions of permanently forested sites were found in the Jura and Swiss Plateau, in particular in the Bernese lowlands (see Figure 1). The highest fraction of young forest sites was observed in mountainous regions, particularly in the Alps and Southern Switzerland.

Environmental conditions potentially influencing SOC stocks varied among the forest age classes. On average, newly afforested sites were located at higher altitudes compared to old forest sites $(1089 \pm 50.3$ vs. $854 \pm 16 \mathrm{~m}$ a.s.l. $)$ and they had a corresponding slightly lower MAT and higher MAP
Figure 3. Forest cover change of the sites throughout the years. Distinction between closed forest, forest edge, and open forest depends on the distance of a site to the mapped forest edge. The sites currently located in closed forest areas $(n=857)$ were used for estimating the minimal forest ages.

Table 1. Cross-comparison of Basic Environmental Variables Between Different Forest Age Categories

\begin{tabular}{|c|c|c|c|c|c|}
\hline Parameters & $<60$ & $60-120$ & $>120$ & Forest age comparison & $p$ adj \\
\hline $\begin{array}{l}\text { Base cations (at } 30 \mathrm{~cm} \text { soil } \\
\text { depth, in mmcolc/kg) }\end{array}$ & $100.1 \pm 13.5$ & $135.2 \pm 10.7$ & $134.8 \pm 6.1$ & $\begin{array}{l}\text { Medium-Young } \\
\text { Old-Young } \\
\text { Old-Medium }\end{array}$ & $\begin{array}{l}\text { n. s. } \\
\text { n. s. } \\
\text { n.s. }\end{array}$ \\
\hline $\mathrm{pH}$ (at $30 \mathrm{~cm}$ soil depth) & $4.8 \pm 0.2$ & $4.9 \pm 0.1$ & $5.0 \pm 0.1$ & $\begin{array}{l}\text { Medium-Young } \\
\text { Old-Young } \\
\text { Old-Medium }\end{array}$ & $\begin{array}{l}\text { n. s. } \\
\text { n. s. } \\
\text { n. s. }\end{array}$ \\
\hline $\begin{array}{l}\text { Clay content (at } 30 \mathrm{~cm} \\
\text { soil depth, in \%) }\end{array}$ & $17.8 \pm 1.2$ & $20.5 \pm 0.8$ & $21.8 \pm 0.5$ & $\begin{array}{l}\text { Medium-Young } \\
\text { Old-Young } \\
\text { Old-Medium }\end{array}$ & $\begin{array}{l}\text { n. s. } \\
0.02 \\
\text { n. s. }\end{array}$ \\
\hline Altitude (m a. s. l.) & $1089.0 \pm 50.3$ & $1000.2 \pm 28.3$ & $854.3 \pm 16$ & $\begin{array}{l}\text { Medium-Young } \\
\text { Old-Young } \\
\text { Old-Medium }\end{array}$ & $\begin{array}{l}\text { n. s. } \\
<0.05 \\
<0.05\end{array}$ \\
\hline Slope (\%) & $50.2 \pm 2.9$ & $41.3 \pm 2$ & $35.1 \pm 1.2$ & $\begin{array}{l}\text { Medium-Young } \\
\text { Old-Young } \\
\text { Old-Medium }\end{array}$ & $\begin{array}{l}0.05 \\
<0.05 \\
0.02\end{array}$ \\
\hline $\operatorname{MAT}\left({ }^{\circ} \mathrm{C}\right)$ & $6.8 \pm 0.3$ & $7.1 \pm 0.1$ & $7.6 \pm 0.1$ & $\begin{array}{l}\text { Medium-Young } \\
\text { Old-Young } \\
\text { Old-Medium }\end{array}$ & $\begin{array}{l}\text { n. s. } \\
<0.05 \\
<0.05\end{array}$ \\
\hline MAP (mm) & $1540.4 \pm 42.3$ & $1388.1 \pm 23.2$ & $1330.3 \pm 12.7$ & $\begin{array}{l}\text { Medium-Young } \\
\text { Old-Young } \\
\text { Old-Medium }\end{array}$ & $\begin{array}{l}<0.05 \\
<0.05 \\
0.07\end{array}$ \\
\hline
\end{tabular}

$P$ values are based on TUkeyHSD ANOVAS, where the means of the forest age categories are compared according to the variables at a confidence level of 0.95 . 
such as Tangel $(n=5)$ and peat $(n=2)$. At 11 sites, organic layers have not been classified. Organic layers had mean SOC stocks of $2.4 \mathrm{~kg} \mathrm{C} \mathrm{m}^{-2}$ and a median of $0.9 \mathrm{~kg} \mathrm{C} \mathrm{m}^{-2}$. Sites in the medium category contained the highest SOC stocks $(3.0 \pm$ $\left.0.3 \mathrm{~kg} \mathrm{C} \mathrm{m}^{-2}\right)$ compared to the young sites $(2.7 \pm$ $\left.0.4 \mathrm{~kg} \mathrm{C} \mathrm{m}^{-2}\right)$ and the old ones $\left(2.2 \pm 0.2 \mathrm{~kg} \mathrm{C} \mathrm{m}^{-2}\right)$. A combination of tree models and expert knowledge was used to identify the most appropriate parameters for the ANOVA model. The final set of parameters included $\mathrm{pH}$ and $\mathrm{BC}$ (mean values at 0-30 cm soil depth, see Table 2), MAT, soil group, forest type, and region, as well as, the following interactions: region $\times$ soil group, soil group $\times B C$, soil group $\times$ forest age, and $p H \times$ forest type. During the manual fit of the model, the interaction soil type $x$ forest age was removed due to insignificance and the interaction region $\times$ soil group due to evidence of multicollinearity. In the final ANOVA model, BC and soil group had the strongest effect on SOC stocks in the organic layer, with the highest SOC stocks in acidic soils, for example, Podzols and Planosols (average $\mathrm{pH}$ of 3.6 for both soil types). Accordingly, $\mathrm{pH}$ had a strong effect, with SOC stocks in the organic layer decreasing with increasing $\mathrm{pH}$. Forest type had also an impact on SOC stocks with conifer sites containing higher SOC stocks in the organic layer than broadleaf sites (3.8 vs. $1.0 \mathrm{~kg} \mathrm{C} \mathrm{m}^{-2}$ ), regardless of forest age (Figure 4). Additionally, organic layer SOC stocks decreased significantly with increasing MAT (Figure 5). The regional distribution showed a significant impact as well, with highest SOC stocks found in the alpine regions (see Electronic supplementary material). The overall model explained $43 \%$ of the variance (adjusted $R^{2}$; Table 2 ).

Forest age only had a marginally significant impact $(P=0.06, \mathrm{SS}=0.4 \%$, see Table 2$)$. Excluding waterlogged soils from the analysis increased the significance of forest age slightly, but the effect remained weak $(P=0.03, \mathrm{SS}=0.6 \%)$. The post hoc TukeyHSD test showed a significant difference in mean SOC stocks between medium forests with a $55 \%$ cover of conifers and old forests with a $48 \%$ conifer cover $(P$ adj $=0.04$ and $P$ adj. $=0.03$, with and without waterlogged soils, respectively).

In the analysis of the individual biogeographic regions in Switzerland, forest age did not significantly affect SOC stocks in the organic layer in any of the regions (see Electronic supplementary material). The effects of forest type, $\mathrm{pH}$, and soil group prevailed in most regions (for example, soil group explained almost $20 \%$ of the model variance in Jura), demonstrating that SOC stocks in the organic layer are influenced primarily by soil chem- istry and forest type. MAT was an important explanatory variable for all regions but Jura. For instance, in the region of the Southern Alps, MAT explained $23 \%$ of the variance.

\section{SOC Stocks in the Mineral Soil (0-120 cm Soil Depth)}

Carbon stocks in the mineral soil (down to a depth of $120 \mathrm{~cm}$ ) showed an overall mean of $10.9 \mathrm{~kg} \mathrm{C} \mathrm{m}^{-2}$ and a median of $9.2 \mathrm{~kg} \mathrm{C} \mathrm{m}^{-2}$. Based on the tree model, soil group, MAP, BC, and sand content (mean values at $0-120 \mathrm{~cm}$ soil depth), as well as slope, altitude, and exposition, were fed into the ANOVA model. In addition, forest age, forest type, region, as well as, the interactions: region $\times$ soil group, soil group $\times$ forest age, and soil group $\times B C$ were added to the model as well. MAP had a strong positive effect on SOC storage $(P<0.05$, Figure 6), explaining a large part of the model variance (sum of squares (SS) $=8.3 \%$, Table 2 ). In addition, soil group was highly significant $(P<0.05)$, with the highest SOC stocks in waterlogged soils. Moreover, there was a negative relationship with slope and sand content and the interaction soil group $\times B C$ was the only interaction to have a significant impact on SOC stocks. Forest age showed a significant impact on SOC stocks $(P<0.05)$; however, its explanatory power (SS $=0.8 \%$ ) was the lowest of all variates. The interaction forest age $\times$ soil group was removed from the model during fitting due to insignificance. Interestingly, the highest SOC stocks were found in the young forest sites $\left(12.5 \pm 0.9 \mathrm{~kg} \mathrm{C} \mathrm{m}^{-2}\right.$, Figure 4) and the lowest ones in old forests $\left(10.5 \pm 0.3 \mathrm{~kg} \mathrm{C} \mathrm{m}^{-2}\right)$. The model explained $32 \%$ of the variance.

When waterlogged soils were excluded, forest age was also found to be significant and had a slightly higher explanatory power $(\mathrm{SS}=1.7 \%)$. However, the effect was considerably smaller compared to other variables. Calcareous and acidic soils had identical SOC stocks in the mineral soil (10.3 $\mathrm{kg} \mathrm{C} \mathrm{m}^{-2}$; n.s.). The ANOVA model explained almost $31 \%$ of the variability. The post hoc TukeyHSD test showed significant differences between the means of the old and medium $(P$ adj $<0.05)$ as well as between old and the young $(P$ adj $<0.05)$ forest age categories.

Among the biogeographical regions, the Southern Alps contained the highest SOC stocks with $15.8,16.9$, and $14.1 \mathrm{~kg} \mathrm{C} \mathrm{m}^{-2}$ for the young, midage, and old forest sites, respectively (Electronic supplementary material). Only the medium forests in Jura had similarly high SOC stocks of 


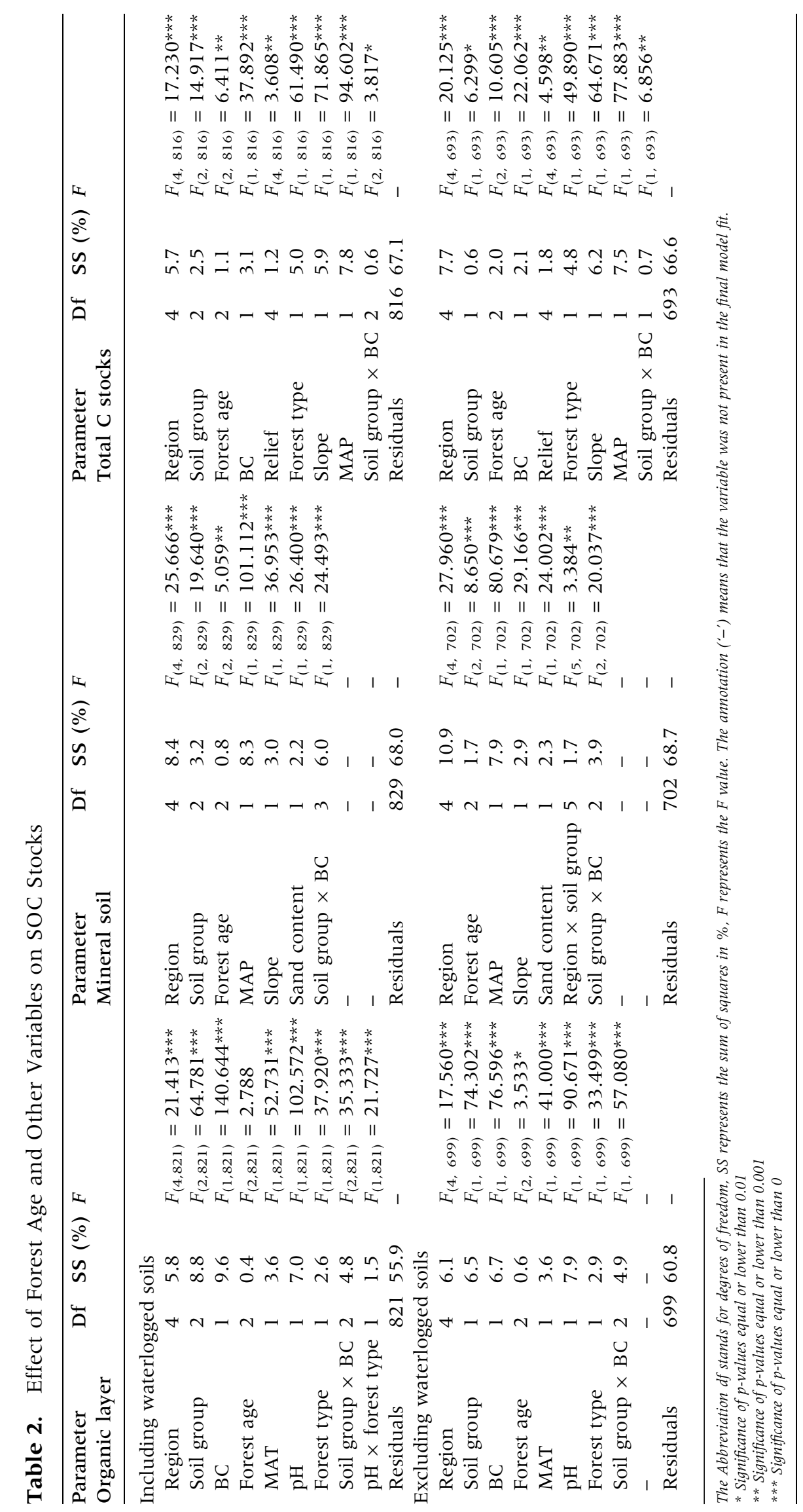




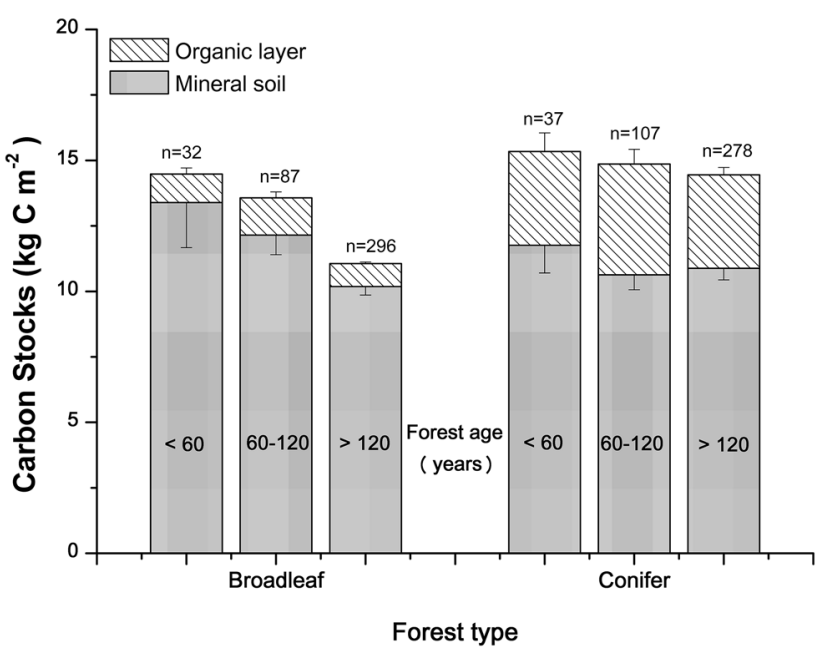

Figure 4. Effects of forest type (broadleaf and conifer) for the three forest age categories on SOC stocks in the organic layer and mineral soil at 0-120 cm soil depth. Error bars represent standard errors.

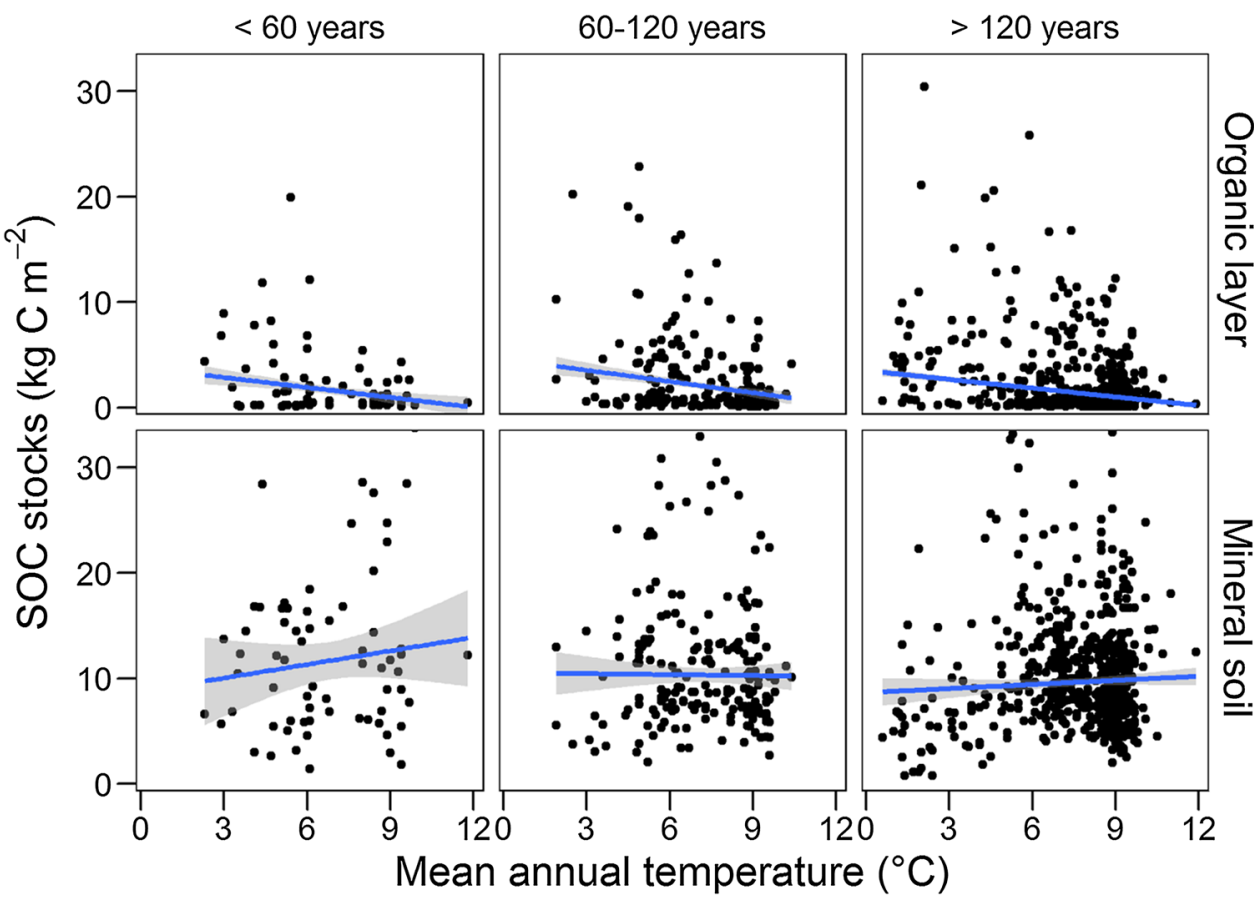

Figure 5. Relationship between SOC stocks $\left(\mathrm{kg} \mathrm{C} \mathrm{m}^{-2}\right)$ in the organic layer and the mineral soil $(0-120 \mathrm{~cm})$ and MAT $\left({ }^{\circ} \mathrm{C}\right)$ for the different forest age categories. Lines represent robust linear regression, areas delineating the lines represent conifidence intervals.

$17.1 \mathrm{~kg} \mathrm{C} \mathrm{m}^{-2}$ in the young forests. Forest age had a marginal significant impact on SOC stocks only in the Alps region, whereas the interaction soil group $x$ forest age was significant in the Swiss Plateau. However, soil group and BC exerted stronger effects in all regions. MAP influenced SOC stocks in all regions except the Jura, whereas forest type and slope were important explanatory variables for the Jura and the Pre-Alps.

A separate analysis of soil data at $0-30 \mathrm{~cm}$ depth showed an almost identical result with forest age not significant and MAP, BC and slope having the strongest effects on SOC stocks (data not shown).

\section{Total SOC Stocks}

Total SOC stocks had an overall mean of $13.3 \mathrm{~kg} \mathrm{C} \mathrm{m}^{-2}$ and a median of $11.6 \mathrm{~kg} \mathrm{C} \mathrm{m}^{-2}$ (data not shown). Based on the tree model, we used the following variables in the ANOVA model: MAT, BC, MAP, slope, soil group, relief as well as the interactions region $\times$ soil group, soil group $\times B C$, and soil group $\times$ forest age in addition to forest age, forest type, and region. The model explained 33\% of the overall variance. The strongest impact was exerted by MAP, followed by slope, region, and forest type (Table 2). SOC stocks were positively 


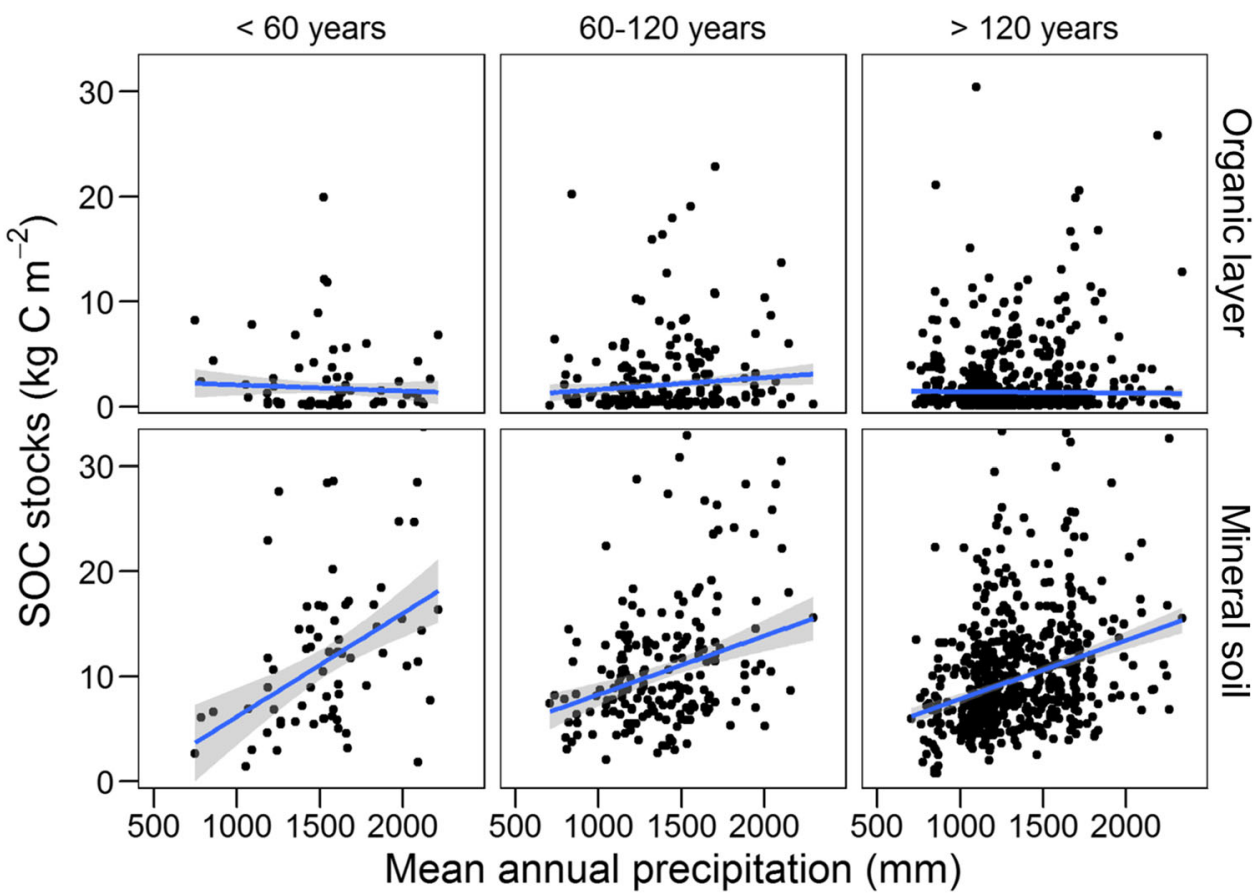

Figure 6. Relationship between SOC stocks in the organic layer and the mineral soil $(0-120 \mathrm{~cm}$ soil depth) and MAP (mm) for the different forest age categories. Lines represent robust linear regression, areas delineating the lines represent conifidence intervals. related to MAP, whereas SOC stocks decreased with increasing slope. Relief was found to also have an impact, with the highest SOC stocks found at foothills. Furthermore, soil group had a significant impact (Figure 7) as well as $\mathrm{BC}$ and the interaction soil group $\times B C$, suggesting that SOC stocks are influenced by the chemical composition of soils. Finally, there was a significant effect of forest type on total SOC stocks, with higher SOC stocks under conifer forests.

Forest age had a significant impact on total SOC stocks $(P<0.05)$, with old forest sites containing the smallest SOC stocks $\left(12.7 \pm 0.3 \mathrm{~kg} \mathrm{C} \mathrm{m}^{-2}\right)$, compared to medium $\left(14.3 \pm 0.5 \mathrm{~kg} \mathrm{C} \mathrm{m}^{-2}\right)$ and young ones $\left(14.9 \pm 1 \mathrm{~kg} \mathrm{C} \mathrm{m}^{-2}\right)$. However, com- pared to the other variables in the ANOVA, forest age explained only a very small percentage of the model variance $(S S=1.1 \%)$. The TukeyHSD test indicated significant differences in the means between old and medium sites $(P$ adj $=0.02)$ and between old and young ( $P$ adj $=0.05)$, but not between the two younger forest groups $(P$ $\operatorname{adj}=0.983)$.

The analysis was additionally performed excluding waterlogged soils, which resulted in a weaker effect of soil group, indicating that total SOC stocks did not differ significantly between acidic and carbonate bedrock. Even though the effect of forest age was more significant $(P<0.05)$ and had a higher explanatory power than with waterlogged

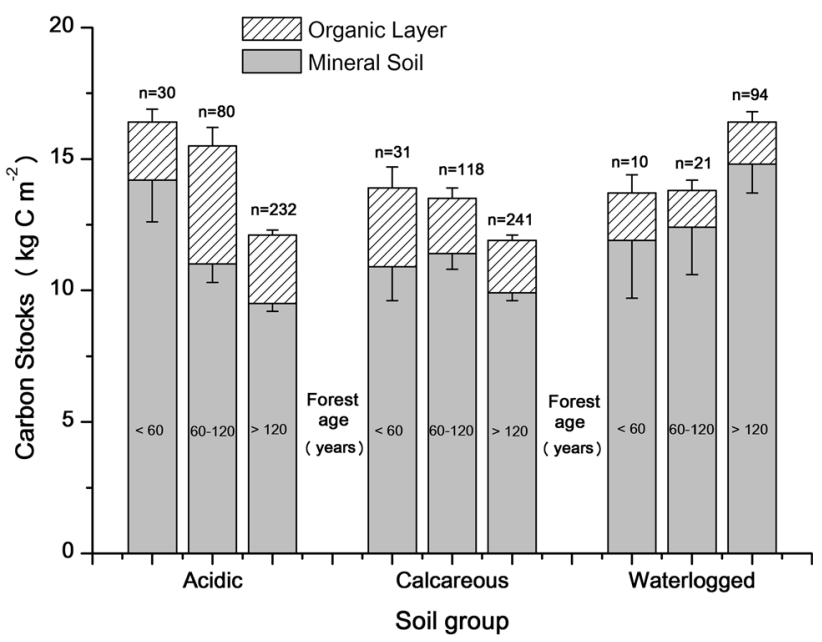

Figure 7. Effects of soil group (acidic, calcareous, and waterlogged) and forest age on SOC stocks $\left(\mathrm{kg} \mathrm{C} \mathrm{m}^{-2}\right)$ in the organic layer and mineral soil at 0-120 cm soil depth, according to the three forest age categories. Error bars represent standard errors. 
soils (SS $=2.0 \%$ ), the influence of other variables was still stronger (Table 2).

A further separation of the young forests into age classes showed average SOC stocks of $16.3 \pm 1.8 \mathrm{~kg} \mathrm{C} \mathrm{m}^{-2}$ for the less-than-20-year-old forest, $14.4 \pm 1.3 \mathrm{~kg} \mathrm{C} \mathrm{m}^{-2}$ for the $20-40$-yearold, and $12.8 \pm 2.2 \mathrm{~kg} \mathrm{C} \mathrm{m}^{-2}$ for the 40-60-yearold forests (see Electronic supplementary material). Hence, also within the young forests, SOC stocks decreased, but too few sites prevented an ANOVA.

\section{Forest Edge Sites}

An additional analysis of forest edges sites (within $25 \mathrm{~m}$ distance from a forest edge) with a consistent forest cover history $(n=76)$ showed that these sites had similar SOC stocks as the closed forest with a mean stock of $2.9 \mathrm{~kg} \mathrm{C} \mathrm{m}^{-2}$ in the organic layer and $11.1 \mathrm{~kg} \mathrm{C} \mathrm{m}^{-2}$ in the mineral soil $(0-120 \mathrm{~cm})$. In agreement with the closed forest, soil chemical variables $(\mathrm{pH}$ and $\mathrm{BC}$ ) had the strongest effect on SOC stocks in the forest edges, whereas forest age was not significant (data not shown).

\section{Discussion}

Our evaluation of historical forest cover for 857 currently forested soil sites revealed that forest age representing forest development on formerly nonforested land had only small effects on SOC stocks in Swiss forest soils with slightly smaller SOC stocks in old than in young forests. In comparison, other factors such as climate and soil chemistry were found to exert a much stronger influence on SOC stocks. The observed small and even negative changes in SOC stocks with forest age challenge the paradigm that mature forests contain the greatest SOC stocks (Lal 2005) and that SOC increases during forest development even several decades after land-use changes (Lettens and others 2004). However, our analysis, based on historical maps, could be biased by significantly different environmental site conditions in the forests of different ages. The comparison of potential drivers for SOC storage revealed that new forest sites were located on average $200 \mathrm{~m}$ in altitude higher than the old ones and at steeper slopes, reflecting that forest expansion due to land abandonment during the last decades has been more pronounced in mountainous regions, while the distribution of landcover types has changed less under more favourable warmer climatic conditions (Gellrich and others 2007; Brändli 2010). Due to the higher elevation, new forest sites had slightly lower mean annual temperatures $\left(-0.8^{\circ} \mathrm{C}\right.$ difference on aver- age) and higher mean annual precipitation $(+210$ $\mathrm{mm}$ difference on average) as compared to the older ones. In comparison, soil properties $(\mathrm{pH}$, soil texture, BC) hardly differed among the forest age categories. Therefore, we assume that our countrywide soil survey using historic maps is largely representative for a chronosequence of forest expansion and development. Applying the observed linear positive relationship between SOC stocks and MAP $\left(+0.0081 \mathrm{~kg}\right.$ SOC $\mathrm{m}^{-2}$ per mm; $R^{2}=0.12^{* * *}$; Figure 6) suggests that the young sites had approximately $1.2-1.7 \mathrm{~kg} \mathrm{C} \mathrm{m}^{-2}$ greater inherent SOC stocks than medium and old forested sites. This estimate is similar to the observed difference of 0.6 and $2.2 \mathrm{~kg} \mathrm{C} \mathrm{m}^{-2}$ between the different forest age categories. We therefore conclude that the 'unbiased' forest age effect is rather small, especially as compared to the $\mathrm{C}$ accumulation in forest biomass. For instance, along an afforestation chronosequence in a subalpine grassland, biomass $\mathrm{C}$ has accumulated $42 \mathrm{~kg} \mathrm{C} \mathrm{m}^{-2}$ during a period of 120 years (Hiltbrunner and others 2013). Furthermore, the Swiss national forest inventory indicates an increase in forest biomass $\mathrm{C}$ due to the ongoing forest expansion and a greater forest growth as compared to wood harvest by almost $0.35 \mathrm{~kg} \mathrm{C} \mathrm{m}^{-2}$ from 1995 until 2005 (Brändli 2010). This comparison indicates that SOC losses with forest development of less than $1 \mathrm{~kg} \mathrm{C} \mathrm{m}^{-2}$ observed here on a centennial time scale are at least an order of magnitude smaller compared to $C$ gains by an increase in forest biomass. In our assessment, we cannot rule out that SOC stocks might have increased during the first decades after forest expansion. However, chronosequence studies rather indicate SOC stocks to decrease initially following afforestation, particularly in the mineral soil (Poeplau and others 2011; Hiltbrunner and others 2013).

To our knowledge, there exists no study with information on historical forest cover and similar site conditions. However, our conclusion that forest age had a small effect on total SOC stocks is corroborated by the results of Wiesmeier and others (2013) in Bavaria (Germany), who found that land use (forest, grassland, cropland) had a smaller impact on SOC stocks as compared to soil type and climate. For the Bavarian Alps, Prietzel and others (2016) even concluded that climatic warming has induced SOC stock losses. Furthermore, Thuille and Schulze (2006) found only negligible effect of afforestation on SOC storage in the Italian Alps, but higher SOC stocks in sites with high precipitation. Our and the other studies are in contrast to the study by Schulp and Verburg (2009) in the 
Netherlands, where historical LUC was found to explain SOC variability better compared to present LUC. Their results, however, are based on four small-scale regions, with a historic transition from open forests and heathlands to agricultural systems on sand areas with Plaggen soil, causing a large additional input of organic matter.

One reason for the apparently small and slightly negative effect of forest cover age on SOC stocks could be litter raking in Swiss forests for several centuries until the early 20th century, which substantially reduced $\mathrm{C}$ inputs into soils of the old forest (Gimmi and others 2013) preventing a SOC accumulation during stand development. Since clear-cutting is not allowed in Switzerland and forest have traditionally been managed as plenter forests (Angst 2012), it seems unlikely that other more severe management practices have reduced SOC storage in old forests as it has been observed in Finland (Peltoniemi and others 2004).

The most likely explanation for the negligible effect of forest cover age on SOC stocks is the dominant historic land use of the newly afforested sites in Switzerland as grasslands, which generally have similar SOC stocks as forests (Poeplau and others 2011). Unfortunately, historical maps do not provide information on the type of previous land use. In their analysis of natural forest regrowth, Gellrich and others (2007) observed that reforestation in Switzerland during a decade between 1980s and 1990s has mostly been taking place on former alpine pastures and grasslands in mountainous regions. Moreover, $85 \%$ of the current agricultural lands above $600 \mathrm{~m}$ a.s.l. are used as grasslands (FOEN 2012) and only $18 \%$ of our young forest sites are below this altitude. We therefore assume that the majority of our young forest sites had once been alpine pastures and marginal grasslands. This assumption is also supported by the fact that afforestation in Europe has taken place to a large extent $(73 \%$ of all afforested lands) on former extensively used grasslands (Vesterdal and others 2011). Although afforestation can strongly affect the microclimate as well as the amounts and quality of litter inputs (Hiltbrunner and others 2013), a number of case studies indicate that the change from grasslands to forests has rather small effects on total SOC stocks. For example, a European-wide land-use change study by Poeplau and Don (2013) observed an impact on SOC stocks for all examined land-use changes except for afforestation on grassland. Two other chronosequence studies in temperate mountainous regions by Thuille and Schulze (2006) and Guidi and others (2014) reported SOC stocks in the mineral soil to even decrease after grassland afforestation. Also the meta-analysis of case studies by Poeplau and others (2011) observed a slight decrease in SOC stocks after grassland afforestation. Thus, if we consider the site conditions in our historical map-based study, we are confident that the negligible and rather negative change in SOC stocks with increasing forest age is robust.

In contrast to our hypothesis that particularly in the organic layer, older forests would have higher SOC stocks we did not observe a consistent pattern. The highest SOC stocks in the organic layer were found in the medium 60- to 120-year-old forests. This pattern is in contradiction to chronosequence studies showing that organic layers are accumulating $\mathrm{C}$ with time following forest expansion, reaching a new equilibrium after 10 to 80 years (Böttcher and Springob 2001; Paul and others 2002; Vesterdal and others 2002; Hiltbrunner and others 2013). The inconsistent pattern in the organic layer can be attributed to the dominance of thin mull-type organic layers, which are biologically very active and reach an equilibrium more rapidly ( $<60$ years) compared to thick mor-type organic layers, where organic matter accumulates at a slower rate. Furthermore, the majority of the medium sites were found in the Pre-Alps and the Alps, areas with relatively thick and SOC-rich organic layers (see Electronic supplementary material). Moreover, the old age group had the lowest contribution of coniferous trees $(48 \%)$ as compared to the two younger ones (55\%) and SOC stocks under coniferous forests contained on average $2.8 \mathrm{~kg} \mathrm{C} \mathrm{m}^{-2}$ higher SOC stocks in the organic layer than under broadleaf forests. However, even when we only included coniferous forests in our analysis, there was no consistent effect of forest age. Our findings of a dominant influence of tree species on SOC storage in the organic layer are supported by the afforestation study by Vesterdal and others (2002), who observed a three times greater increase in SOC stocks during afforestation with spruce than with oak. Furthermore, the study on past forest management by Wäldchen and others (2013) concluded that SOC stocks are affected by tree species but not by past forest management. Therefore, the selection and promotion of tree species would be a potential management practice to increase SOC storage in forests (Vesterdal and others 2013; Wiesmeier and others 2013).

In our study, other factors such as climate, soil group and soil chemistry exerted a much stronger effect on SOC stocks than forest age. Our conclusion is confirmed by the studies in Bavaria by Wiesmeier and others $(2012,2014)$, observing soil 
type to have a dominant influence on SOC storage. In Switzerland, there are particularly high SOC stocks in the acidic 'black' soils of the Southern Alps, which contain high contents of iron and aluminium oxides and large amounts of fire-derived 'stable' organic matter (Eckmeier and others 2010). Moreover, climate had a considerable effect on SOC storage both in the organic layer and the mineral soil with a negative relation of SOC stocks to MAT in the organic layer, and a positive with MAP in the mineral soil. The strong effects of MAT and MAP on SOC storage are in agreement with numerous other studies (Vesterdal and others 2011 ; Doblas-Miranda and others 2013; GabarrónGaleote and others 2015). These relationships suggest that the expected climate changes with increasing temperatures and higher frequencies of drought (Akademien der Wissenschafften Schweiz 2016) will lead to smaller SOC stock in mountainous regions as it has been observed in warming experiment and repeated soil surveys (Schindlbacher and others 2009; Streit and others 2014; Prietzel and others 2016).

Historical, present, and future land-use change is considered as a main driver of terrestrial $C$ storage (Ciais and others 2013). It is expected that terrestrial ecosystems in the Northern hemisphere currently act as a net C sink (Gutman and others 2012; Janssens and others 2003) due to high afforestation rates, agricultural land abandonment and reduced wood harvest. Soil C modelling suggests that after a change in land management SOC storage follows a sigmoidal increase with the strongest increase after several decades (Jandl and others 2007). Furthermore, a modelling study forest $\mathrm{C}$ dynamics for the Swiss Plateau and the Alps by Thürig and Kaufmann (2010) expects that an increasing $C$ input by a reduced forest management will increase SOC stocks for several decades. In recent estimates of the climate balance through forest expansion in mountainous regions, Schwaab and others (2015) showed that $C$ sequestration in biomass and soils is, however, largely outbalanced by an increased radiative forcing through albedo changes under the assumption that forests would accumulate soil C during stand development. Our study strongly suggests-in conjunction with other case studies-that ongoing forest expansion and development in Switzerland and probably also in other mountainous temperate regions in Europe is not associated with an increased $\mathrm{C}$ sequestration in soils, deteriorating the climate balance of terrestrial ecosystems. Therefore, we conclude that Switzerland and mountainous countries with similar forest covers and grassland as previous land use influence the European carbon balance to a lesser extent than previously projected and depend on regional variations in the climate, the vegetation, and the soil properties.

\section{ACKNOWLEDGEMENTS}

We gratefully thank Christin Loran for the help with outlining the Dufour map and Barbara Schneider for the support with the Siegfried tool. Evaluations were based on data from the Swiss Long-term Forest Ecosystem Research programme LWF (www.lwf.ch), which is part of the UNECE Co-operative Programme on Assessment and Monitoring of Air Pollution Effects on Forests ICP Forests (www.icp-forests.net). We are in particular grateful to Dr. Peter Waldner for the provision of the LWF data, to Oliver Schramm for the collection of the data, as well as, to Peter Jakob for the technical support database. Furthermore, we would like to thank Sonia Meller, Dr. Emily Solly, Dominik Brödlin, Martin Ley, Dr. Thomas Rime and Claude Herzog (WSL) for fruitful discussions, as well as, Beatriz González Domínguez, Dr. Mirjam Studer, Cédric Bader, and Tessa van der Voort for their input and synergy. This study (SNF 406840_143025) was funded by the Swiss National Fond (SNF) within the National Research Programme 68 (Sustainable Use of Soil as a Resource).

\section{Compliance with Ethical Standards}

Conflict of intereset The authors declare no conflict of interest.

\section{REFERENCES}

Achat DL, Fortin M, Landmann G, Ringeval B, Augusto L. 2015. Forest soil carbon is threatened by intensive biomass harvesting. Nat Sci Rep 5:15991. doi:10.1038/srep15991.

Akademie der Wissenschaften Schweiz. 2016. Brennpunkt Klima Schweiz. Grundlagen, Folgen und Perspektiven. Swiss Acad Rep 11(5):34-45.

Angst M. 2012. Integration of Nature Protection in Swiss Forest Policy. INTEGRATE Country Report for Switzerland. Country report within the framework of the research project INTEGRATE (Integration of nature protection in forest management and its relation to other functions/services) of the Central European Office of the European Forest Institute (EFICENT), Freiburg I.B. [published online July 2012] Available from World Wide Web http://www.wsl.ch/ publikationen/pdf/11873.pdf. Birmensdorf, Swiss Federal Research Institute for Forest, Snow and Landscape, WSL. 76 S.

Bárcena TG, Kiæer LP, Vesterdal L, Stefánsdóttir HM, Gundersen P, Sigurdsson BD. 2014. Soil carbon stock change following afforestation in Northern Europe: a meta-analysis. Glob Change Biol 20:2393-405. 
Bolliger J, Hagedorn F, Leifeld J, Böhl J, Zimmermann S, Soliva R, Kienast F. 2008. Effects of land-use change on carbon stocks in Switzerland. Ecosystems 11:895-907.

Böttcher J, Springob G. 2001. A carbon balance model for organic layers of acid forest soils. J Plant Nutr Soil Sci 164:399-405.

Braun-Blanquet J. 1964. Pflanzensoziologie Grundzüge der Vegetationskunde. 3rd edn. Berlin: Springer.

Brändli U-B (Red.). 2010. Schweizerisches Landesforstinventar. Ergebnisse der dritten Erhebung 2004-2006. Birmensdorf, Eidgenössische Forschungsanstalt für Wald, Schnee und Landschaft WSL. Bern, Bundesamt für Umwelt, BAFU. 312 S.

Brändli U-B, Cioldi F, Fischer C, Huber M. 2015. Swiss National Forest Inventory-Special assessments for the Forest Report 2015 in the internet. WSL, Birmensdorf. Online: www.lfi.ch/ publ/waldbericht/2015-en.php [17.8.15].

Ciais P, Sabine C, Bala G et al. 2013. Carbon and other biogeochemical cycles. Climate Change 2013 Physical Science Basis Contribution to Working Group I to Fifth Assessment Report of the Intergovernmental Panel on Climate Change, pp. 465570. doi:10.1017/CBO9781107415324.014

Crawley MJ. 2007. Regression. The R book. Hoboken: Wiley.

Doblas-Miranda E, Rovira P, Brotons L, Martínez-Vilalta J, Retana J, Pla M, Vayreda J. 2013. Soil carbon stocks and their variability across the forests, shrublands and grasslands of peninsular Spain. Biogeosciences 10:8353-61. doi:10.5194/bg-10-8353-2013.

Dupouey JL, Dambrine E, Laffite JD, Moares C. 2002. Irreversible impact of past land use on forest soils and biodiversity. Ecology 83(11):2978-84. doi:10.2307/3071833.

Eckmeier E, Egli M, Schmidt MWI, Schlumpf N, Nötzli M, Minikus-Stary N, Hagedorn F. 2010. Preservation of fire-derived carbon compounds and sorptive stabilisation promote the accumulation of organic matter in black soils of the Southern Alps. Geoderma 159:147-55.

FOEN. 2012. Switzerland's Greenhouse Gas Inventory 19902010. National Inventory Report 2012 including reporting elements under the Kyoto Protocol; Federal Office for the Environment Bern.

Fuchs R, Schulp CJE, Hengeveld GM, Verburg PH, Clevers JGPW, Schelhaas M-J, Herold M. 2016. Assessing the influence of historic net and gross land changes on the carbon fluxes of Europe. Glob Change Biol 22:2526-39. doi:10.1111/gcb.13191.

Gabarrón-Galeote MA, Trigalet S, van Wesemael B. 2015. Effect of land abandonment on soil organic carbon fractions along a Mediterranean precipitation gradient. Geoderma 249-250:6978. doi:10.1016/j.geoderma.2015.03.007.

Gee GW, Bauder JW. 1986. Particle-size analysis. In: Klute A, Ed. Methods of soil analysis. Part 1. 2nd ed. Agronomy monograph 9. Madison, WI: ASA and SSSA. pp. 383-411.

Gellrich M, Baur P, Zimmermann NE. 2007. Natural forest regrowth as a proxy variable for agricultural land abandonment in the Swiss mountains: a spatial statistical model based on geophysical and socio-economic variables. Environ Model Assess J 12:269-78. doi:10.1007/s10666-006-9062-6.

Gimmi U, Poulter B, Wolf A, Portner H, Weber P, Bürgi M. 2013. Soil carbon pools in Swiss forests show legacy effects from historic forest litter raking. Landsc Ecol 28:835-46.

Ginzler C, Brändli UB, Hägeli M. 2011. Waldflächenentwicklung der letzten 120 Jahre in der Schweiz. Schweiz Z Forstwes $162: 337-43$.

Gnägi C, Labhart T. (2015) Geologie der Schweiz, 9, vollständig überarbeitete Auflage, ott verlag, 208 Seiten. ISBN 978-37225-0142-0.
Gonseth Y, Wohlgemuth T, Sansonnens B, Buttler A. 2001. Die biogeographischen Regionen der Schweiz. Erläuterungen und Einteilungsstandard. Bern: Bundesamt für Umwelt Wald und Landschaft.

Guidi C, Vesterdal L, Gianelle D, Rodeghiero M. 2014. Changes in soil organic carbon and nitrogen following forest expansion on grassland in the Southern Alps. For Ecol Manag 328:10316.

Guillaume T, Damris M, Kuzyakov Y. 2015. Losses of soil carbon by converting tropical forest to plantations: erosion and decomposition estimated by $\alpha^{13} \mathrm{C}$. Glob Change Biol 21:354860. doi:10.1111/gcb.12907.

Guo LB, Gifford RM. 2002. Soil carbon stocks and land use change: a meta analysis. Glob Change Biol 8:345-60.

Gutman G et al., Eds. 2012. Land change science. Remote sensing and digital image processing, vol 6. doi:10.1007/9781-4020-2562-4_14.

Hagedorn F, Moeri A, Walthert L, Zimmermann S. 2010. Kohlenstoff in Schweizer Waldböden-bei Klimaerwärmung eine potenzielle $\mathrm{CO} 2-$ Quelle. Schweizerisch Zeitschrift für Forstwesen 161(12):530-5.

Harrell FE Jr, et al., with contributions from C. D. and many. 2015. Hmisc: Harrell Miscellaneous. R package version 3.16-0. http://cran.r-project.org/package $=$ Hmisc.

Heiberger RM. 2015. HH: Statistical analysis and data display: Heiberger and Holland. R package version 3.1-2l. at http:// cran.r-project.org $/$ package $=\mathrm{HH}$.

Hiltbrunner D, Zimmermann S, Hagedorn F. 2013. Afforestation with Norway spruce on a subalpine pasture alters carbon dynamics but only moderately affects soil carbon storage. Biogeochemistry 115:251-66.

IUSS Working Group WRB. 2007. World Reference Base for Soil Resources 2006, first update 2007, World Soil Resources Reports No. 103, FAO, Rome.

Jandl R, Lindner M, Vesterdal L et al. 2007. How strongly can forest management influence soil carbon sequestration? Geoderma 137:253-68.

Janssens IA, Freibauer A, Ciais P et al. 2003. Europe's terrestrial biosphere absorbs 7 to $12 \%$ of European anthropogenic $\mathrm{CO}_{2}$ emissions. Science 300(5625):1538-42. doi:10.1126/science. 1083592.

Kümmerle T, Kaplan JO, Prishchepov AV, Rylsky I, Chaskovskyy O, Tikunov VS, Müller D. 2015. Forest transitions in Eastern Europe and their effects on carbon budgets. Glob Change Biol 21:3049-61. doi:10.1111/gcb.12897.

Lal R. 2005. Forest soils and carbon sequestration. For Ecol Manag 220:242-58.

Lemon J. 2006. Plotrix: a package in the red light district of R. RNews 6:8-12.

Lettens S, Van Orshoven J, van Wesemael B, Perrin D, Roelandt C. 2004. The inventory-based approach for prediction of SOC change following land use change. Biotechnol, Agron, Soc Environ (BASE) 8(2):141-6.

Liski J, Perruchoud D, Karjalainen T. 2002. Increasing carbon stocks in the forest soils of western Europe. For Ecol Manag 169(1-2):159-75.

Lorenz K, Lal R. 2010. Carbon sequestration in forest ecosystems. Berlin: Springer. doi:10.1007/978-90-481-3266-9_1

Mobley ML, Lajtha K, Kramer MG, Bacon AR. 2015. Surficial gains and subsoil losses of soil carbon and nitrogen during secondary forest development. Glob Change Biol 21:986-96. doi:10.1111/gcb.12715. 
Motzkin J, Bellemare G, Foster DR. 2002. Legacies of the agricultural past in the forested present: an assessment of historical land-use effects on rich mesic forests. J Biogeogr 29:1401-20.

Neuwirth E. (2014) RColorBrewer: ColorBrewer Palettes. R package version 1.1-2. http://cran.r-project.org/package $=$ RColorBrewer.

Nussbaum M, Papritz A, Zimmermann S, Wathert S. 2016. Pedotransfer function to predict denisty of forest soils in Switzerland. J Plant Nutr Soil Sci 179:321-6. doi:10.1002/jpln. 201500546.

Paul KI, Polglase PJ, Nyakuengama JG, Khanna PK. 2002. Change in soil carbon following afforestation or reforestation. For Ecol Manag 168:241-57.

Peltoniemi M, Mäkipää R, Liski J, Tamminen P. 2004. Changes in soil carbon with stand age-an evaluation of a modelling method with empirical data. Glob Change Biol 10:2078-91. doi:10.1111/j.1365-2486.2004.00881.x.

Poeplau C, Don A, Vesterdal L, Leifeld J, van Wesemaels B, Schumacher J, Gensior A. 2011. Temporal dynamics of soil organic carbon after land-use change in the temperate zone-carbon response functions as a model approach. Glob Change Biol 17:2415-27.

Poeplau C, Don A. 2013. Sensitivity of soil organic carbon stocks and fractions to different land-use changes across Europe. Geoderma 192:189-201. doi:10.1016/j.geoderma.2012.08.003.

Prietzel J, Zimmermann L, Schubert A, Christophel D. 2016. Organic matter losses in German Alps forest soils since the 1970s most likely caused by warming. Nat Geosci 9:543-8. doi:10.1038/NGEO2732.

Remund J, Rihm B, Huguenin-Landl B. 2014. Klimadaten für die Waldmodellierung für das 20. und 21. Jahrhundert Schlussbericht. Forschungsprogramm „Wald und Klimawandel“ des Bundesamtes für Umwelt BAFU, Bern und der Eidg. Forschungsanstalt WSL, Birmensdorf. Meteotest, Bern.

R Core Team. 2015. R: a language and environment for statistical computing. Vienna: R Foundation for Statistical Computing. https://www.r-project.org/.

Ripley B. 2015. Tree: classification and regression trees. R package version 1.0-36. http://cran.r-project.org/package=tree.

Rounsevell MD, Annetts J, Audsley E, Mayr T, Reginster I. 2003. Modelling the spatial distribution of agricultural land use at the regional scale. Agr Ecosyst Environ 95:465-79.

Rounsevell MD, Reginster I, Araújo MB et al. 2006. A coherent set of future land use change scenarios for Europe. Agr Ecosyst Environ 114:57-68.

Scharlemann JPW, Tanner EVJ, Hiederer R, Kapos V. 2014. Global soil carbon: understanding and managing the largest terrestrial carbon pool. Carbon Manag 5(1):81-91. doi:10. $4155 / \mathrm{cmt} .13 .77$.

Schindlbacher A, Zechmeister-Boltenstern S, Jandl R. 2009. Carbon losses due to soil warming: do autotrophic and heterotrophic soil respiration respond equally? Glob Change Biol 15(4):901-13. doi:10.1111/j.1365-2486.2008.01757.x.

Schmidt MWI, Torn MS, Abiven S et al. 2011. Persistence of soil organic matter as an ecosystem property. Nature 478:49-56.

Schulp CJE, Verburg PH. 2009. Effect of land use history and site factors on spatial variation of soil organic carbon across a physiographic region. Agr Ecosyst Environ 133:86-97.

Schwaab J, Bavay M, Davin E et al. 2015. Carbon storage versus albedo change: radiative forcing of forest expansion in temperate mountainous regions of Switzerland. Biogeosci Discuss 11:10123-65.
Sjögersten S, Alewell C, Cécillon L et al. 2011. Mountain soils in a changing climate-vulnerability of carbon stocks and ecosystem feedbacks. Soil Carbon Sensit Eur Ecosyst From Sci Land Manag. doi:10.1002/9781119970255.ch6.

Spielvogel S, Prietzel J, Kögel-Knabner I. 2006. Soil organic matter changes in a spruce ecosystem 25 years after disturbance. Soil Sci Soc Am J 70:2130-45. doi:10.2136/sssaj2005. 0027.

Streit K, Hagedorn F, Hiltbrunner D, Portmann M, Saurer M, Buchmann N, Wild B, Richter A, Wipf S, Siegwolf RTW. 2014. Soil warming alters microbial substrate use in alpine soils. Glob Change Biol 20(4):1327-38. doi:10.1111/gcb.12396.

Swisstopo. 2011. DEM, Swisstopo.

Thuille A, Schulze E-D. 2006. Carbon dynamics in successional and afforested spruce stands in Thuringia and the Alps. Glob Change Biol 12:325-42. doi:10.1111/j.1365-2486.2005.01078.x.

Thürig E, Kaufmann E. 2010. Increasing carbon sinks through forest management: a model-based comparison for Switzerland with its Eastern Plateau and Eastern Alps. Eur J For Res 129:563-72. doi:10.1007/s10342-010-0354-7.

Venables WN, Ripley BD. 2002. Modern applied statistics with S. 4 th edn. New York: Springer.

Vesterdal L, Ritter E, Gundersen P. 2002. Change in soil organic carbon following afforestation of former arable land. For Ecol Manag 169(1-2):137-47.

Vesterdal L, Leifeld J, Poeplau C, Don A, van Wesemael B. 2011. Land-use change effects on soil carbon stocks in temperate regions-development of carbon response functions. In: Jandl $\mathrm{R}$, Rodeghiero $\mathrm{M}$, Olsson $\mathrm{M}$, Eds. Soil carbon in sensitive european ecosystems: from science to land management. Chichester: Wiley. doi:10.1002/9781119970255.ch3

Vesterdal L, Clarke N, Sigurdsson BD, Gundersen P. 2013. Do tree species influence soil carbon stocks in temperate and boreal forests? For Ecol Manag 309:4-18. doi:10.1016/j. foreco.2013.01.017.

Walthert L, Graf U, Kammer A, Luster J, Pezzotta D, Zimmermann S, Hagedorn F. 2010. Determination of organic and inorganic carbon, $\delta 13 \mathrm{C}$, and nitrogen in soils containing carbonates after acid fumigation with HCl. J Plant Nutr Soil Sci 173:207-16.

Walthert L, Graf Pannatier E, Meier ES. 2013. Shortage of nutrients and excess of toxic elements in soils limit the distribution of soil-sensitive tree species in temperate forests. For Ecol Manag 297:94-107.

Wickham H. 2007. Reshaping data with the reshape package. J Stat Softw 21:1-20.

Wickham H. 2009. ggplot2: elegant graphics for data analysis. New York: Springer.

Wickham H. 2011. The Split-Apply-Combine Strategy for Data Analysis. J Stat Softw 40:1-29.

Wickham H. 2015. tidyr: Easily Tidy Data with 'spread()' and 'gather()' Functions. R package version 0.3.1. http://cran.rproject.org $/$ package $=$ tidyr.

Wickham H. and Francois R. 2015. dplyr: a grammar of data manipulation. $\mathrm{R}$ package version 0.4 .3. http://cran.r-project. org $/$ package $=$ dplyr.

Wiesmeier M, Spörlein P, Geuß U et al. 2012. Soil organic carbon stocks in southeast Germany (Bavaria) as affected by land use, soil type and sampling depth. Glob Change Biol 18(7):1365-2486. doi:10.1111/j.1365-2486.2012.02699.x.

Wiesmeier M, Prietzel J, Barthold F et al. 2013. Storage and drivers of organic carbon in forest soils of southeast Germany 
(Bavaria)-implications for carbon sequestration. For Ecol Manag 295:162-72.

Wiesmeier M, Barthold F, Spörlein P et al. 2014. Estimation of total organic carbon storage and its driving factors in soils of Bavaria (southeast Germany). Geoderma Reg 1:67-78. doi:10. 1016/j.geodrs.2014.09.001.
Wäldchen J, Schulze E-D, Schöning I, Schrumpf M, Sierra C. 2013. The influence of changes in forest management over the past 200 years on present soil organic carbon stocks. For Ecol Manag 289:243-54. 